\title{
A study about gender economic equality in India
}

\author{
HEMANGI D. MEHTA, JIJU N. VYAS AND RINA RENSIYA
}

Received: 26.04.2017; Revised: 26.10.2017; Accepted: 10.11.2017

See end of the paper for authors' affiliations

\section{HEMANGI D. MEHTA}

Polytechnic in Home Science, Junagadh Agricultural University, Keriya Road, AMRELI (GUJARAT) INDIA

Email : hemangidmehta@gmail. com
ABSTRACT : The term 'Gender equality' narrates the equal valuing of the different roles assumed by men and women. The theme strives to overcome stereotype barriers and prejudices so both men and women are capable of equally reaping benefits and contributing towards social, political, cultural and economic developments within society. When men and women enjoy equality, the direct outcome is an instant and stable growth in economy. The educated and healthy women in a society are more supportive and accommodating towards their families and nations. but Gender pay gap in India refers to the difference in earnings between women and men in the paid employment and labor market . A report by the World Economic Forum highlights that in the corporate sector in India, has been economic participation and opportunity too ranked $136^{\text {th }}$ out of 144 countries on the Global Gender Gap Report 2016. India has climbed 3 spots from $139^{\text {th }}$ position in 2015. a woman is paid only one-third of what a man in the same position is paid. Thus, in addition to unequal pay, there is also unequal representation, because while women constitute almost half the Indian population (about $48 \%$ of the total), their representation in the work force amounts to only about one-fourth of the total.

KEY WORDS: Economic participation, Opportunity, Gender gap, Economic empowerment

- HOW TO CITE THIS PAPER : Mehta, Hemangi D., Vyas, Jiju N. and Rensiya, Rina (2017). A study about gender economic equality in India. Asian J. Home Sci., 12 (2) : 558-560, DOI: 10.15740/HAS/AJHS/ 12.2/558-560. 